\title{
REESCRITA TEXTUAL: UM DIÁLOGO ENTRE A PRÁTICA DOCENTE E A DISCENTE
}

\author{
TEXTUAL REWRITING: A DIALOGUE BETWEEN TEACHER \\ PRACTICE AND STUDENT
}

Claudine Alves Willemann ${ }^{1}$

\begin{abstract}
"Chega mais perto e contempla as palauras. Cada uma tem mil faces secretas sob a face neutra e te pergunta, sem interesse pela resposta, pobre ou terrivel, que lhe deres:

Trouxeste a chave?"

(Carlos Drummont de Andrade: 2012)
\end{abstract}

\section{Resumo}

Este artigo tem como objetivo discutir a relevância ou não da reescrita de textos produzidos por alunos, para o aprimoramento de suas produções, na esfera escolar, considerando como objeto de investigação o processo de produção textual, desde sua primeira versão até sua reelaboração, por meio da análise de textos de alunos do $9^{\circ}$ Ano do Ensino Fundamental II, a partir dos apontamentos feitos pelo professor, por meio de sua correção. Procurouse compreender o diálogo estabelecido entre o aluno e o professor e entre o professor e o aluno, durante o processo de elaboração, correção e reelaboração do texto. Entretanto, ao comparar as produções textuais

\footnotetext{
${ }^{1}$ Licenciada em Letras pela Universidade Católica Dom Bosco - MS (1999); é especialista em Metodologia do Ensino da Língua Portuguesa pela Universidade para o Desenvolvimento do Estado e da Região do Pantanal - MS (2003). Devido ao grande interesse pela linguagem escrita, cursou a Extensão Universitária em Análise do Discurso: O que é, como se faz? Leitura e Escrita pela Pontificia Universidade Católica de São Paulo (2016) e, atualmente, é mestranda no Instituto de Psicologia da USP, desenvolvendo pesquisa na área da aquisição da linguagem escrita. Com carreira desenvolvida na atividade docente, já foi professora do Ensino Fundamental I e II, nos estados de Mato Grosso do Sul e Goiás, e hoje atua como professora de Língua Portuguesa do Ensino Fundamental II e Ensino Médio no Colégio Vértice, em São Paulo.
}

Interfaces da Educ., Paranaíba, v.10, n.28, p. 117 à 143, 2019 ISSN 2177-7691

Recebido em Novembro de 2018/ Aprovado em Abril de 2019 
reelaboradas, percebe-se que em algumas há, de fato, a melhoria do texto, porém em outras, há um retrocesso. Os fundamentos teóricos que deram suporte para essa análise, principalmente, foram os estudos sobre reescrita de Cavalcanti (2015) e sobre correção de Ruiz (2015), entre outros. Pelas observações feitas, notou-se que a estratégia de correção escolhida pelo professor tem influência na dinâmica adotada pelo aluno em sua reescrita. Infelizmente, os dados obtidos mostraram que, em sua maioria os alunos não demonstram grande esforço e envolvimento com esse tipo de atividade.

Palavras-chave: Produção de texto, reescrita textual, correção de texto, análise crítica.

\section{Abstract}

This article aims to discuss the relevance or not of the rewriting of texts produced by students, for the improvement of their productions, in the school sphere, considering as object of investigation the textual production process, from its first version to its reworking, through of the analysis of texts of students of the $9^{\text {th }}$ grade, based on the notes made by the teacher, through their correction. We searched to understand the dialogue established between the student and the teacher and between the teacher and the student, during the process of preparation, correction and re-elaboration of the text. However, when comparing the reworked textual productions, one can notice that in some there is, indeed, the improvement of the text, but in others, there is a retrogression. The theoretical fundaments that supported this analysis were the studies on rewriting by Cavalcanti (2015) and on the correction of Ruiz (2015), among others. From the observations made, it was noticed that the correction strategy chosen by the teacher influences the dynamics adopted by the student in his rewriting. Unfortunately, the data obtained showed that, in it's majority, the students do not show great effort and involvement with this type of activity.

Keywords: Text production. Rewrinting. Text Correction. Critical Analysis.

\section{Introdução}


Hoje, muito se tem discutido e investido na prática de produções textuais em sala de aula, visando habilitar o aluno a produzir seus próprios textos, colocando-o como sujeito de sua escrita. Entretanto, sabe-se que o processo de produção textual não se finda no texto em si, é preciso ir além, é necessário que o estudante reflita sobre sua produção, analisando-a, e, se necessário, melhorando-a por meio da reescrita.

Logo, visando analisar essa etapa posterior à produção do texto, desenvolveu-se o presente estudo, "Reescrita textual: diálogo entre a prática docente e a discente", a fim de averiguar se a reescrita, a partir das observações feitas pelo professor e pelo próprio aluno, é, de fato, uma estratégia válida para o aprimoramento da escrita do aluno.

A atualidade desse assunto se dá pela recente Base Nacional Comum Curricular (BNCC) - documento que norteia a Educação Básica Brasileira, assegurando a todos os alunos o direito à aprendizagem e ao desenvolvimento, homologada em 20 de dezembro de 2017 - que apresenta a produção textual como um dos eixos fundamentais para o componente curricular de língua portuguesa, reconhecendo seu caráter processual, ou seja, defendendo um trabalho mais sistemático, desde sua elaboração a sua reescrita, como pode ser visto no trecho a seguir:

\begin{abstract}
EF69LP07) Produzir textos em diferentes gêneros, considerando sua adequação ao contexto produção e circulação - os enunciadores envolvidos, os objetivos, o gênero, o suporte, a circulação -, ao modo (escrito ou oral; imagem estática ou em movimento etc.), à variedade linguística e/ou semiótica apropriada a esse contexto, à construção da textualidade relacionada às propriedades textuais e do gênero), utilizando estratégias de planejamento, elaboração, revisão, edição, reescrita/redesign e avaliação de textos, para, com a ajuda do professor e a colaboração dos colegas, corrigir e aprimorar as produções realizadas, fazendo cortes, acréscimos, reformulações, correções de concordância, ortografia, pontuação em textos e editando imagens, arquivos sonoros, fazendo cortes, acréscimos, ajustes, acrescentando/ alterando efeitos, ordenamentos etc. (BNCC, p. 142)
\end{abstract}

Portanto, para que este estudo tornasse-se possivel, foram analisadas 77 reescritas de alunos de três turmas de 9os Anos do Ensino Fundamental II, sendo o $9^{\circ} \mathrm{A}$, o $9^{\circ} \mathrm{B}$ e o $9^{\circ} \mathrm{C}$, de uma escola privada, situada na Zona Sul 
de São Paulo, no bairro Campo Belo. Porém, a fim de se compreender o processo da reescrita do aluno, observou-se também, a proposta de redação oferecida aos alunos, sua primeira versão do texto, as intervenções feitas pela professora durante o processo de avaliação/correção, a análise crítica realizada pelo próprio aluno e, por fim, sua reescrita.

Nessa etapa final, tendo como objeto de estudo a reescrita, buscou-se perceber se o aluno fora capaz de absorver todas as observações feitas, tanto pela professora quanto por ele próprio, empregando ou não, em sua nova versão, elementos necessários para o aperfeiçoamento de seu texto.

\section{As diferentes etapas da atividade proposta:}

\section{A Proposta de Redação}

A atividade que resultou na primeira versão do texto foi aplicada durante uma avaliação bimestral, em que o aluno contava apenas com a proposta de redação - composta por uma coletânea de dois textos motivadores - e com seu repertório sociocultural adquirido por meio de discussões promovidas em aula, durante todo o bimestre.

É importante destacar que a temática proposta permeou todas as atividades desenvolvidas no bimestre, possibilitando um contato intenso do aluno com o assunto em questão, pois, conforme defende Cavalcanti (2015, p. 163), "não se pode discutir temas sobre os quais não se tem informações, não se conhece diferentes pontos de vista".

A proposta a ser desenvolvida pelos alunos era assim composta:

Proposta de Redação: (a) editorialista de um jornal de grande circulação. Com base nas reportagens a seguir e em seu conhecimento, adquirido ao longo de nossas discussões neste bimestre, produza o editorial que circulará em edição posterior da mesma instituição, apresentando e defendendo seu ponto de vista com relação ao tema "Brasil: um pais de fato acolhedor?"

\section{Coletânea - textos motivadores:}


Texto I - Venezuelanos sobrecarregam serviços públicos em $R R$, que vive crise fiscal

Disponivel em :

https://www1.folha.uol.com.br/mundo/2018/08/venezuelanossobrecarrega m-servicos-publicos-em-rr-que-vive-crise-fiscal.shtml

\section{Texto II - Imigrantes voltam para Venezuela após violência em Roraima}

Disponivel em https://www1.folha.uol.com.br/mundo/2018/09/imigrantesvoltam-para-a-venezuela-apos-violencia-em-roraima.shtml

\section{Produção e correção da primeira versão}

De acordo com Benveniste, "é na linguagem e pela linguagem que o homem se constitui como sujeito" (2005, p. 286), e, é a partir de sua produção textual que o aluno, partindo de um eu, passa a dialogar com o outro, um tu, expressando seu posicionamento acerca do tema proposto.

Diante dessa concepção, Cayer, Crestani e Diedrich (2016, p. 1417), afirmam que a prática da escrita só é válida quando o aluno tem consciência dessa interação entre sujeitos, ou seja, "se a palavra vem de alguém, ela se dirige a alguém - sem essa dualidade, não existe interação e o texto descaracteriza-se de sua função primordial”.

De forma geral, analisando as produções feitas pelos alunos, notou-se que compreenderam bem a proposta de redação, uma vez que todos os alunos produziram o gênero textual solicitado - um editorial -, seguindo sua estrutura e suas características, abordando e desenvolvendo o tema, uns de forma mais aprofundada, outros de maneira bastante superficial, colados aos textos motivadores.

Todos os textos foram corrigidos pela professora, seguindo a concepção de correção de Ruiz (2015, p.19), que a reconhece como "o trabalho que o professor faz por escrito no (e de modo sobreposto ao) texto do aluno, para falar desse mesmo texto". Para isso, a professora adotou critérios estabelecidos por meio de uma grade de correção, que reconhecia, não só aspectos gramaticais, mas, principalmente, o texto de forma holística, avaliando sua estrutura; composição textual - introdução, tese, 
argumentação e conclusão; bem como aspectos referentes à coesão e à coerência, além de averiguar-se a progressão textual e a construção de uma unidade de sentido.

\section{A correção: diálogo do docente com o texto do aluno}

A correção nada mais é do que um diálogo do professor com o aluno, pois o docente incorpora o papel de leitor do texto, ou seja, assume a posição do $t u$, observando o desenvolvimento do tema proposto, o encadear das ideias, a composição de uma linha de raciocínio.

Esse diálogo, ou melhor, essa correção, de acordo com Ruiz (2015), pode ser realizada de diferentes formas, classificando-se em cinco tipos, sendo eles:

a) $\boldsymbol{A}$ correção indicativa: na qual os erros são indicados ao aluno por meio de algum tipo de sinalização, podendo ser verbal ou não, na margem ou no próprio corpo do texto;

\section{Exemplo 1:}

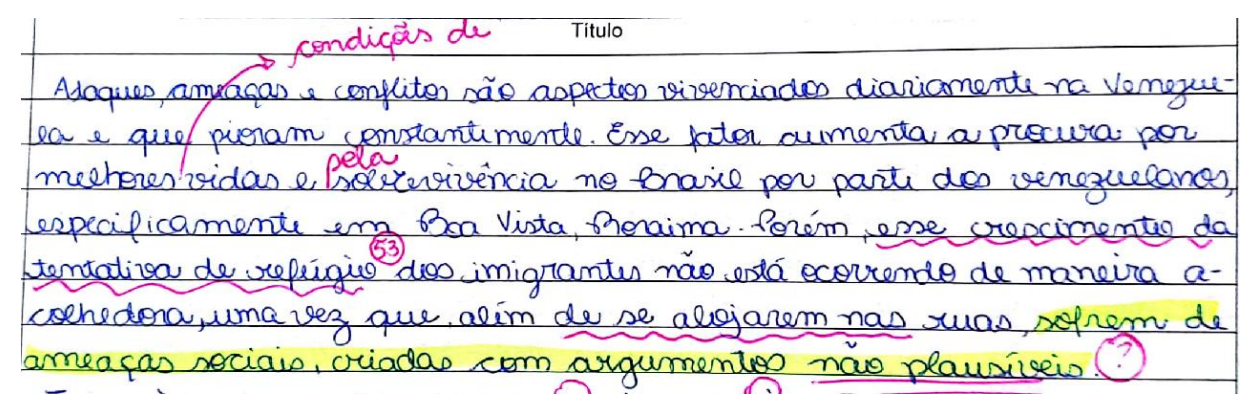

Embora haja outras formas de correção presentes nesse trecho, há o predominio de algumas marcas indicativas, como o uso de um sublinhado em forma de ondas e o traçado duplo acompanhado por um ponto de interrogação entre um círculo. Esse tipo de correção, denominada por Ruiz (2015, p. 64) como "indicativa "pura", não colabora para uma boa revisão feita pelo aluno, uma vez que "não fornece pistas suficientes", logo, muitas 
vezes, o estudante vê-se diante de um enigma que não é possivel ser solucionado.

Por exemplo, o aluno seria capaz de identificar qual o problema existente no trecho "de se alojarem nas", já que o sublinhado não está acompanhado de nenhuma outra observação? O mesmo ocorre em "não plausiveis". Diante de marcações como essas, o aluno, em uma proposta de reescrita, ou opta por fazer alteração alguma, ou age na intuição, uma vez que não sabe, de fato, o que tais marcações significam.

b) A correção resolutiva: em que o professor, ao ler e avaliar o texto do aluno, já sugere a solução para os problemas encontrados, inserindo, na maior parte das vezes, no corpo do texto, nas margens ou após o texto, sugestões que julga serem adequadas para deixar o trecho correto. Esse tipo de correção demanda tempo e muito esforço, pois, conforme afirma Ruiz (2015, p. 41), “é uma tentativa de o professor assumir, pelo aluno, a reformulação de seu texto". Pode ser feita por meio de substituição, adição, supressão e deslocamento.

\section{Exemplo 2:}

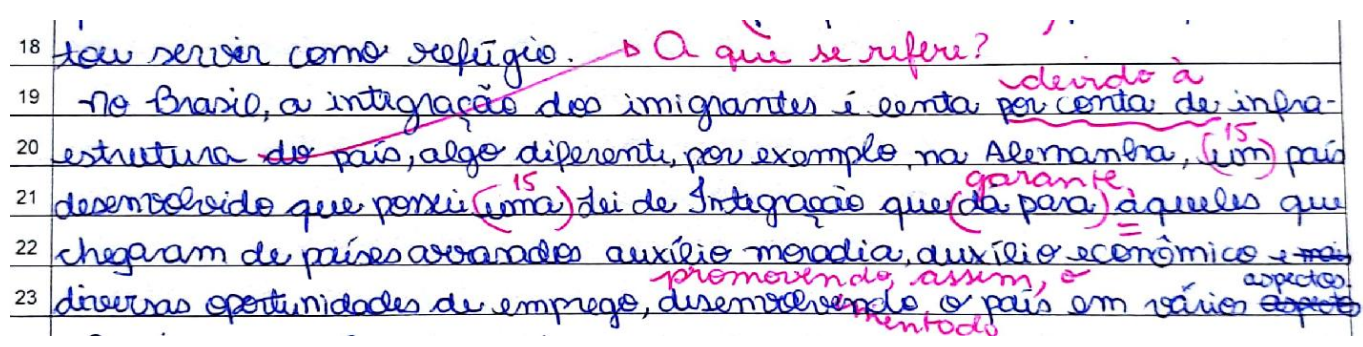

Nesse trecho, percebe-se que a professora identificou alguns problemas no texto e já propôs a solução, escrevendo logo acima da escrita do aluno a forma como ela julgou que o texto ficaria mais adequado.

Frente a esse tipo de correção, o aluno, ao ser desafiado a reescrever seu texto, apenas copia as alterações apresentadas, dessa forma, como defende Ruiz (2015, p. 61), “muito pouco será aproveitado pelo aluno no que se refere à tarefa de reescrita”, já que não haverá reflexão acerca de sua produção. 
Ruiz defende ainda que "ao monopolizar o trabalho da revisão, o professor passa a ideia de que essa tarefa é sua, não do aluno", logo, o aluno não assume a responsabilidade de rever seu próprio texto para encontrar aspectos que deveriam ser aprimorados. Portanto, diante de uma correção resolutiva, não se pode afirmar que o diálogo entre professor e aluno seja eficiente.

c) A correção classificatória: ocorre por meio de um conjunto de símbolos pré-estabelecidos, em que cada símbolo corresponde a um problema encontrado. Logo, o aluno, ao se deparar com um desses símbolos, deverá averiguar de que se trata e fazer as alterações esperadas.

\section{Exemplo 3:}

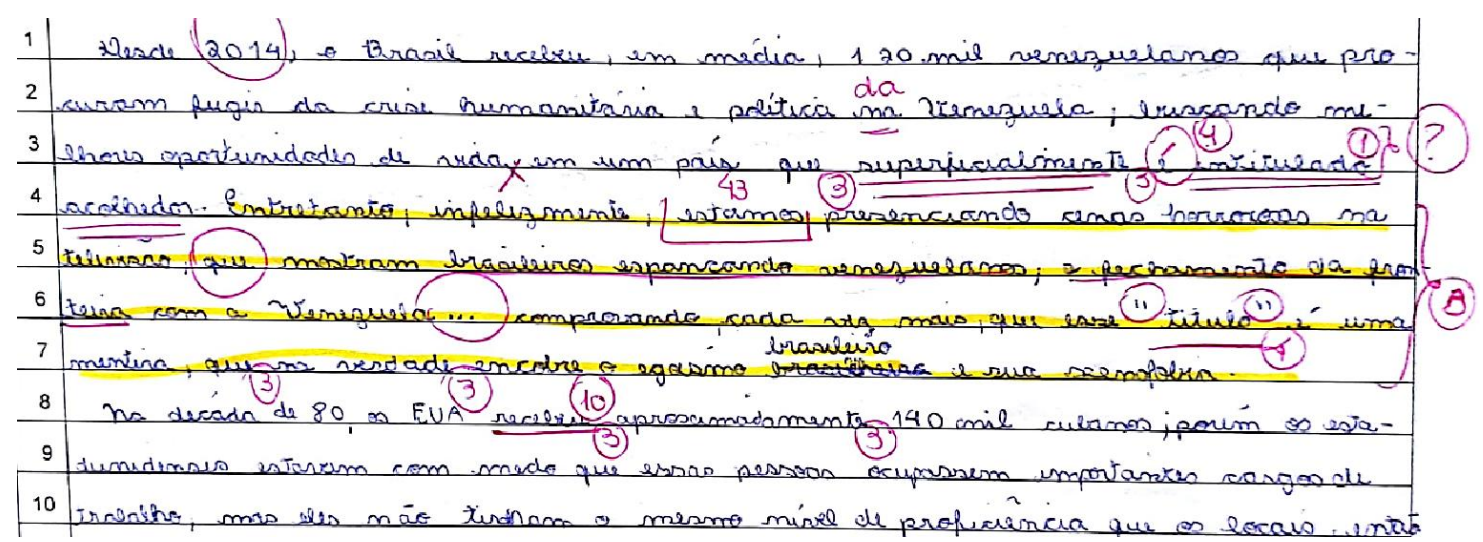

Nota-se, nesse trecho, em maior quantidade, a presença da correção classificatória, ou seja, a professora, por meio de uma tabela já pré-definida, envolvendo algarismos correspondentes a determinadas transgressões, pontuou os problemas presentes na produção do aluno.

Diante desses códigos, o aluno vê-se obrigado a consultá-los na tabela e a corrigi-los em sua reescrita; porém, assim como na correção indicativa, Ruiz (2015, p. 70) afirma que, muitas vezes, o aluno não consegue "encontrar uma solução para o problema focalizado", dessa forma ou opta por mantê-lo em sua reelaboração, ou substitui o trecho ou termo por aquilo que ele julga ser mais apropriado intuitivamente.

Tabela utilizada pela professora para a correção classificatória: 


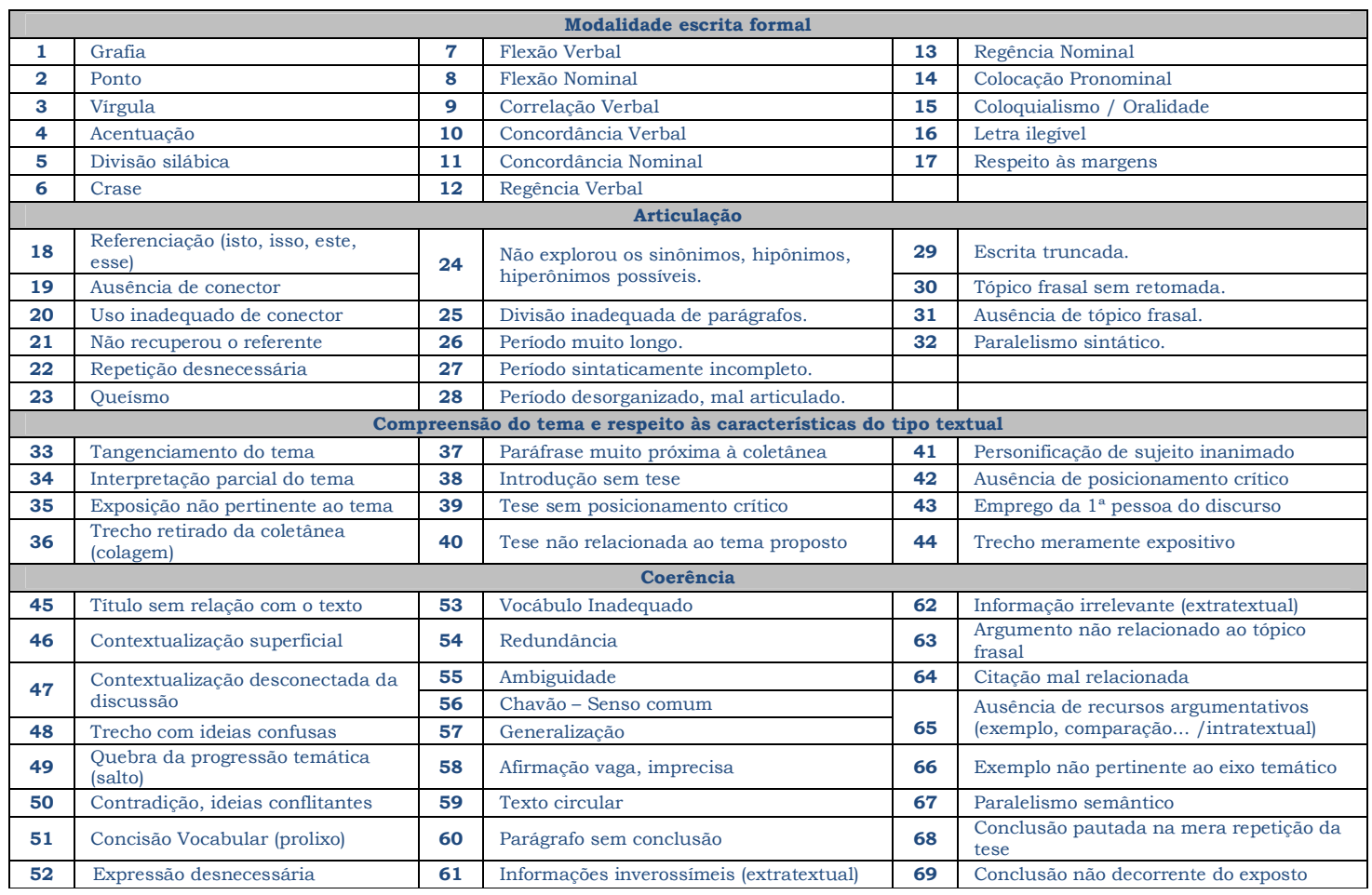

d) A correção textual-interativa: o professor, por meio de "bilhetes" (Ruiz: 2015), dialoga com seu aluno, normalmente após o texto, ou em um espaço reservado exatamente para essa função, através de comentários que evidenciem aspectos a serem aprimorados.

\section{Exemplo 4:}

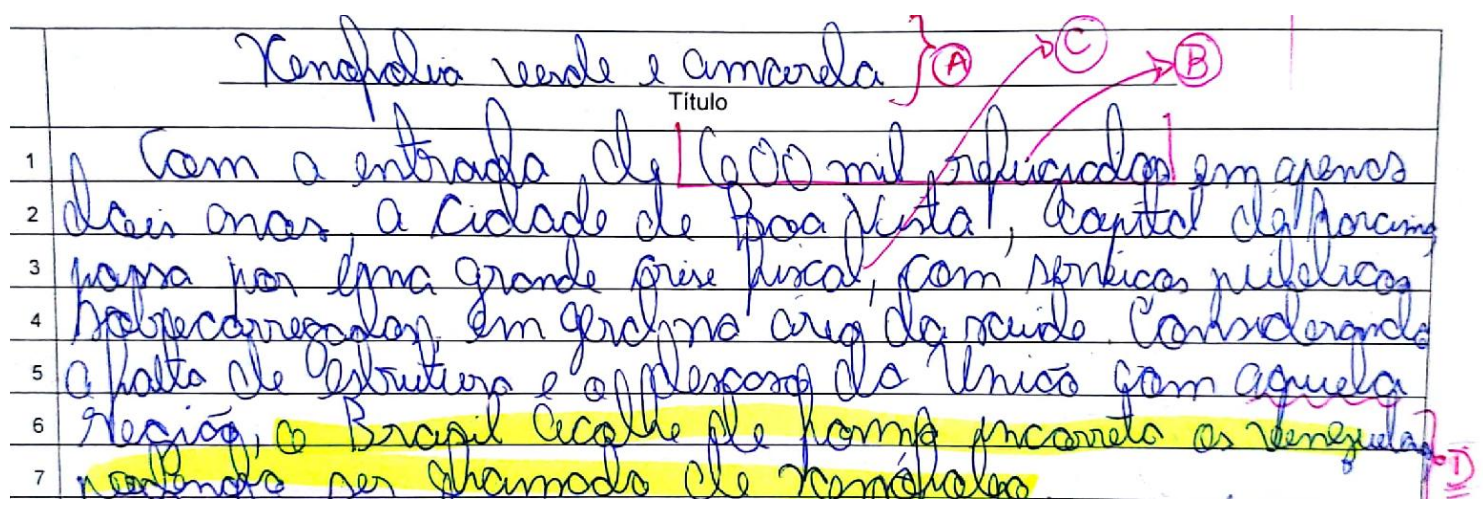




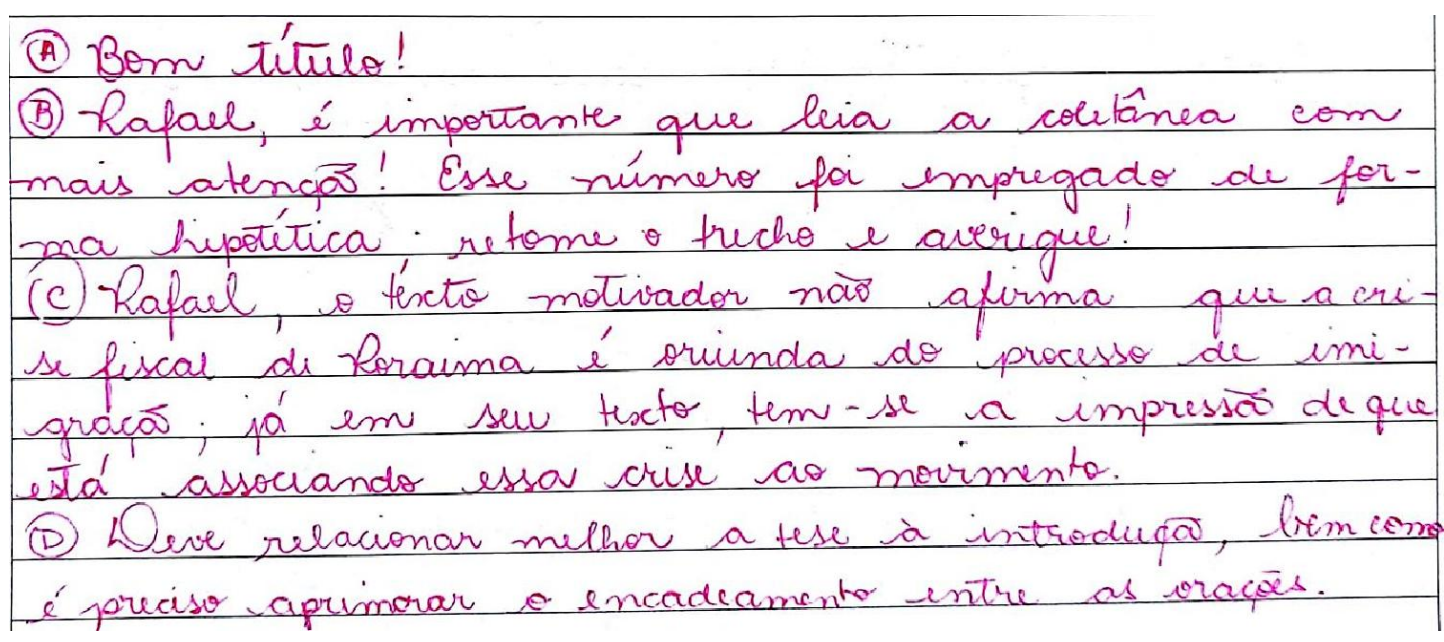

Nesse trecho, percebe-se que a professora optou por não registrar suas observações no corpo do texto do aluno, mas, sim, em deixar pequenos "bilhetes" após a produção.

Para Ruiz (2015, p. 52), a correção textual-interativa é "a forma alternativa encontrada pelo professor para dar conta de apontar, classificar ou até mesmo resolver aqueles problemas de redação do aluno que, por alguma razão, ele percebe que não basta via corpo, margem ou símbolo".

Como é o caso dos bilhetes presentes no exemplo acima, em que um código ou uma resposta resolutiva não seriam capazes de contemplar os apontamentos feitos.

Analisando esses pequenos excertos de textos de alunos, nota-se que a professora em questão não adota uma única forma de correção, mesclando os diferentes tipos, entretanto, percebe-se o predomínio de duas delas: a classificatória e a textual-interativa.

\section{Análise critica da produção textual}

Após a correção, os alunos foram convidados a analisar seus próprios textos, seguindo um roteiro elaborado pela professora:

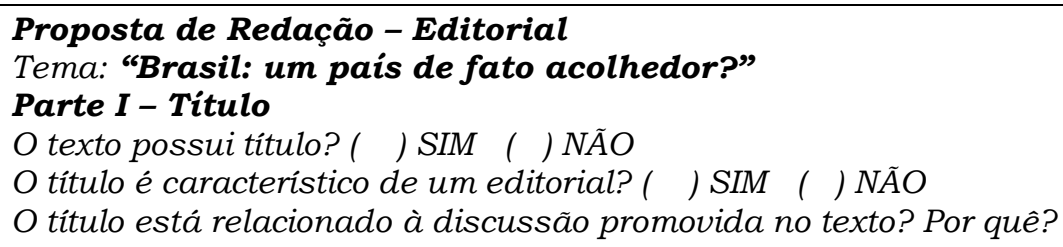




\section{Parte II - Introdução}

O texto apresenta gancho com a reportagem lida? ( ) SIM ( ) NÃO

Que informações retiradas da reportagem foram utilizadas para iniciar seu texto?

O gancho apresentado foi eficiente na apresentação do assunto? ( ) SIM ( ) NÃO

$O$ texto apresenta tese? (Trata-se realmente de um posicionamento, e, não de um fato)

( ) $S I M($ )NÃO

A tese está de acordo com o tema proposto? ( ) SIM ( )NÃO

A tese está clara? É fácil identificá-la? ( ) SIM ( ) NÃO

Reescreva sua tese:

Portanto, a tese pretende provar que...

\section{Parte III - Desenvolvimento/Argumentação}

Quantos parágrafos compõem o desenvolvimento do texto? Quais são eles?

Quantos argumentos foram empregados para fundamentar sua tese?

Observando cada um desses parágrafos, responda:

Que tipo de recurso argumentativo foi empregado? Cite e comprove (de forma breve, pontual).

Os argumentos foram retirados/baseados na coletânea ou são parte de um repertório sociocultural externo a ela? Explique.

É possivel afirmar que os argumentos foram eficientes na defesa da tese? ( )SIM ( )NÃO Por quê?

\section{Parte IV - Conclusão}

O texto apresenta conclusão? ( )SIM ( )NÃO

Empregou conjunção conclusiva para iniciar sua conclusão? Qual?

A conclusão tem relação com a discussão proposta? ( )SIM ( )NÃO

Sua conclusão retoma sua tese? ( )SIM ( )NÃO

Ou apresenta sugestão para o problema apresentado? ( )SIM ( )NÃO

Caso tenha apresentado proposta de intervenção, pode-se afirmar que foi elaborada de forma completa? ( ) SIM ( ) NÃO

Com base em sua proposta, preencha o roteiro a seguir:

AÇÃO:

AGENTE:

MEIO:

FINALIDADE:

Pode-se dizer que a conclusão foi eficiente na finalização do texto? ( )SIM ( )NÃO

Por quê?

\section{Parte V-Linguagem}

Seu texto é pessoal (emprego da $1^{a}$ pessoa)? ( )SIM ( )NÃO

Seu texto é impessoal (escrito na $3^{a}$ pessoa)? ( )SIM ( )NÃO

Emprega linguagem formal? ( )SIM ( )NÃO

*Qual foi a intervenção de correção que mais apareceu em seu texto? A que associa esse problema?

Preencha o esquema a seguir com informações retiradas de seu texto:

\section{Tema: "Brasil: um pais de fato acolhedor?"}

Gancho:

Interfaces da Educ., Paranaíba, v.10, n.28, p. 117 à 143, 2019

ISSN 2177-7691 


\begin{tabular}{|l|}
\hline Pressuposto: \\
\hline Argumentos: \\
\hline Conclusão: \\
\hline
\end{tabular}

Observação: Na ficha oferecida aos alunos, o número de linhas para resposta era maior, entretanto, neste trabalho, optou-se por reduzi-lo para otimizar o espaço.

Essa autoavaliação do aluno sobre seu próprio texto é muito importante, uma vez que, de acordo com Cavalcanti (2015, p. 161), esse momento proporciona ao estudante a análise de sua produção, averiguando se é adequada e eficaz àquilo a que se propõe, "trata-se de um momento extremamente importante, indispensável no processo da escrita, que demanda que o escrevente ocupe a posição de leitor, avaliando o que é necessário eliminar, acrescentar, modificar".

É por meio dessa reflexão que o estudante desloca-se da posição do eu (autor do texto) e passa a assumir a posição do tu (leitor do texto), a fim de que, verdadeiramente, possa observar os aspectos a serem modificados em sua produção.

Normalmente, espera-se que o aluno, conforme defende Ruiz (2015, p. 20), se veja como "o primeiro leitor de si mesmo", isto é, que, após rascunhar seu texto, revise-o, observando sua escrita, a clareza das informações apresentadas, seu encadeamento e, principalmente, sua coerência, além de outros elementos textuais de grande importância para a composição de um texto, como a progressão textual. Entretanto, sabe-se que, muitas vezes, o aluno passa seu texto a limpo sem, ao menos, reler seu esboço, mesmo ciente de que seu professor será o principal leitor de sua produção.

Partindo dessa premissa é que a professora proporcionou aos alunos esse momento de reflexão, para que, após analisarem seus textos minuciosamente, estivessem preparados para reescrevê-los, buscando aprimorá-los de acordo com todas as observações feitas. 


\section{Proposta de Reescrita}

A prática da reescrita, lamentavelmente, ainda é pouco explorada nas salas de aula brasileiras, seja pela falta de preparo do professor, seja pelo tempo necessário a ser dedicado à correção (Cavalcanti, 2015, p. 20).

Além dessas questões, também é preciso que se reflita acerca da correção realizada pelo professor, uma vez que, de acordo com Ruiz (2015, p. 26), sua responsabilidade é enorme, "pois de sua interpretação da redação a ser retextualizada dependerá a interpretação (leitura) que o aluno fará dessa mesma redação e, portanto, grande parte do próprio processo de retextualização".

Analisando a reescrita das 77 redações, observou-se que em 16 casos os alunos apenas realizaram uma "simples higienização" (Cavalcanti, 2015, p. 161), ou seja, corrigiram somente aquilo que fora evidenciado pela professora no próprio texto, sem que houvesse aprimoramento quanto à seleção de argumentos e/ou ampliação do tema.

Em 32 redações, notou-se na reescrita certo descaso, pois os alunos realizaram uma limpeza bastante superficial do texto, deixando escapar um ou outro erro apontado na correção; além disso, além de não aprimorarem o que deveriam ter melhorado, reduziram algumas passagens, simplificando ainda mais a produção.

Apenas em 29 redações foi possivel perceber uma evolução no texto, ou seja, nesses casos, os alunos foram muito além de uma "simples higienização", analisaram os aspectos apontados pela professora e empenharam-se em buscar soluções para os pontos a serem aprimorados.

\section{Gráfico 1}




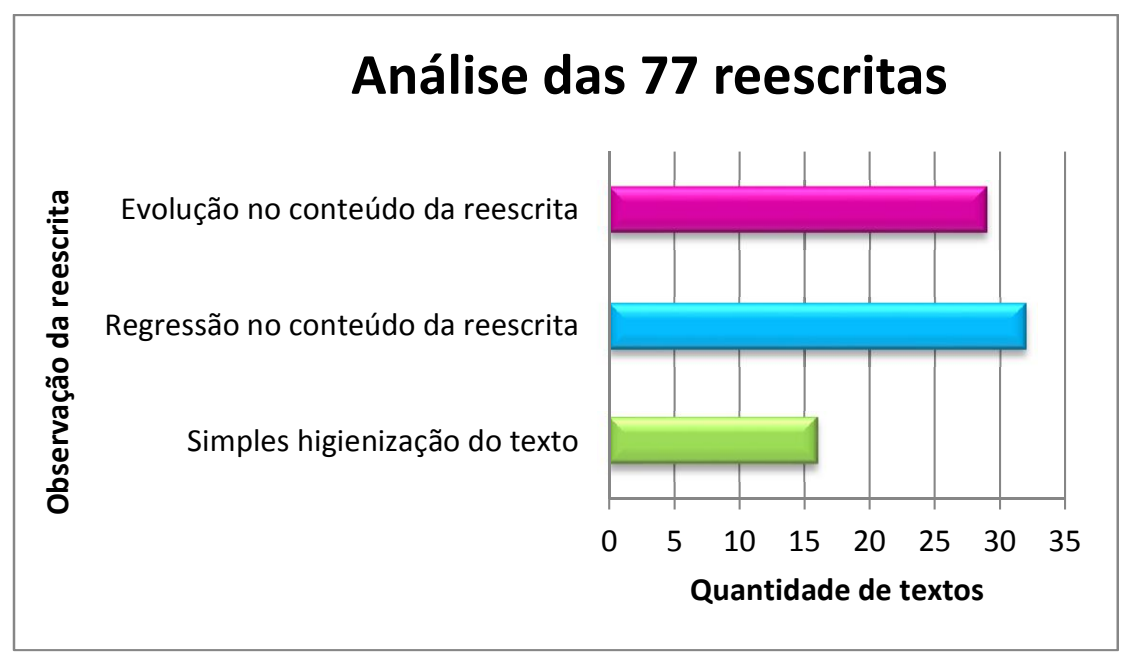

Resultado da análise da reescrita dos alunos, observando as alterações feitas

\section{Análise das reescrita: um diálogo possivel?}

\section{Simples Higienização do Texto}

Comparando a primeira versão do texto com sua reescrita, notou-se que, em 16 casos dos 77 textos observados, os alunos apenas "higienizaram" a primeira versão de seu texto, corrigida pela professora, conforme denomina Cavalcanti (2015, p. 161), ou seja, os alunos corrigiram somente os erros evidenciados no corpo de sua produção. Logo, nesses casos, pode-se afirmar que o diálogo entre a professora e o aluno, estabelecido por meio das intervenções, não foi eficiente, já que não houve avanço no conteúdo de seu texto.

Parte desse insucesso atribui-se à correção, já que, devido à presença da correção resolutiva, há, por parte do aluno, certo comodismo, pois as alterações a serem feitas já estão prontas, logo não é necessário envolver-se na correção para que haja aprimoramento. Assim, o aluno realiza seu trabalho de forma superficial, uma vez que já foi realizado pela professora.

\section{Exemplificação de reescrita em que houve apenas higienização do texto} $1^{a}$ Versão 


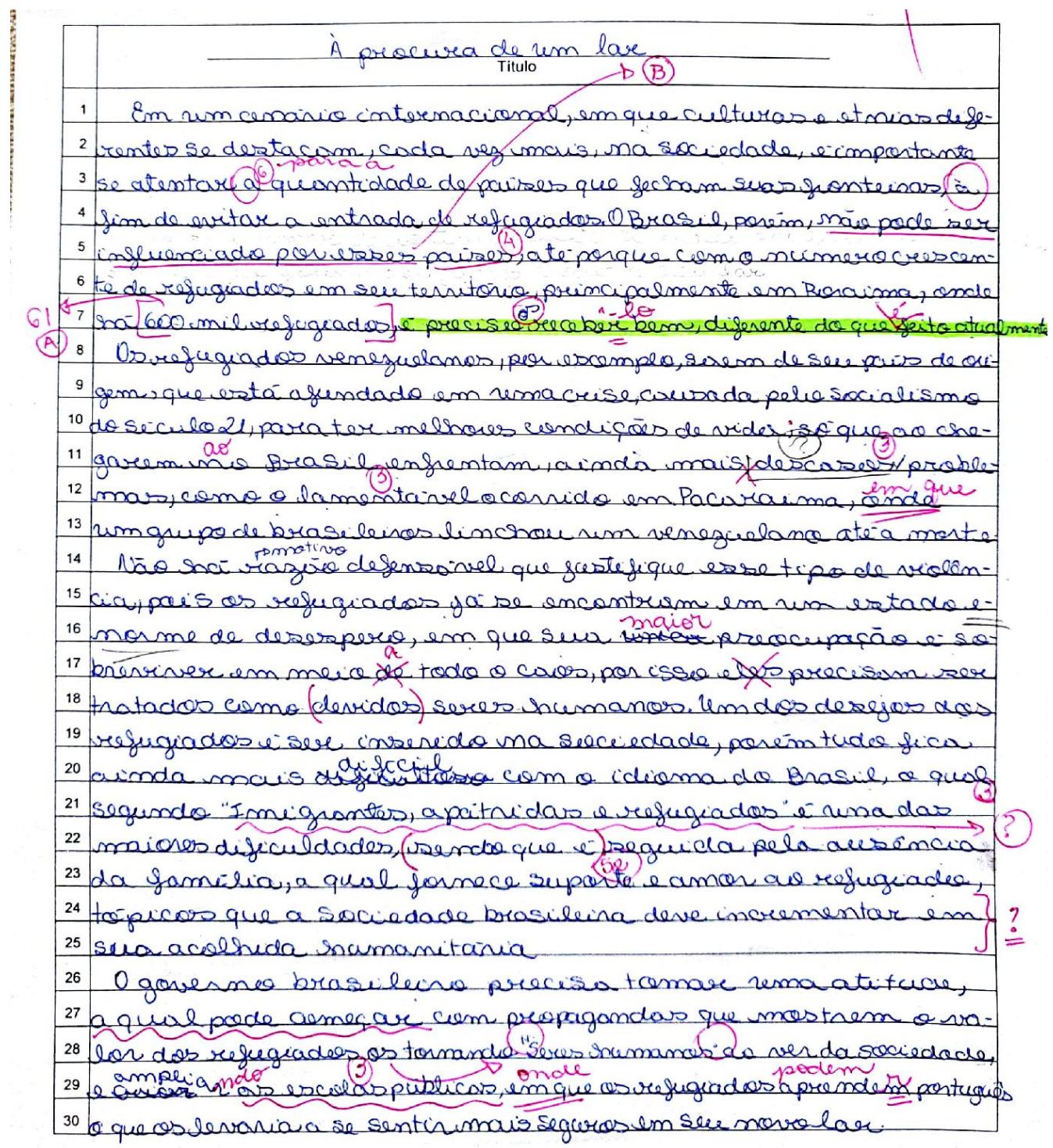

Obs.: Os códigos utilizados por meio de algarismos são os mesmos da tabela apresentada anteriormente, já aqueles por meio de letras encontram-se em forma de "bilhetes" após o texto.

\section{Comentários feitos pela professora após o texto:}




\begin{tabular}{|c|}
\hline COMENTÁRIOS \\
\hline 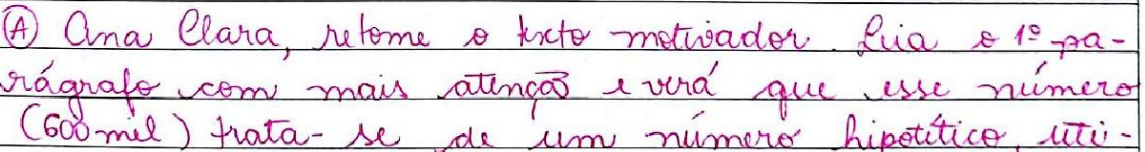 \\
\hline $\begin{array}{l}\text { lizpdo pela jornalista para aproximar o litor do } \\
\text { fato. }\end{array}$ \\
\hline (3) Deve yustificar sua afirmagias \\
\hline $\begin{array}{l}\text { Ana, sew texto apresenta boa progressas de fa- } \\
\text { tos e iduas, só é preciso que retome alguns tre- } \\
\text { chos (final do } 3 \text { parágrafo) a fim de aprumerá-los }\end{array}$ \\
\hline
\end{tabular}

Como é possivel observar, a professora empregou todos os tipos de correção abordados nesse estudo, predominando a resolutiva e a

\section{indicativa.}

\section{$2^{\mathrm{a}}$ Versão}

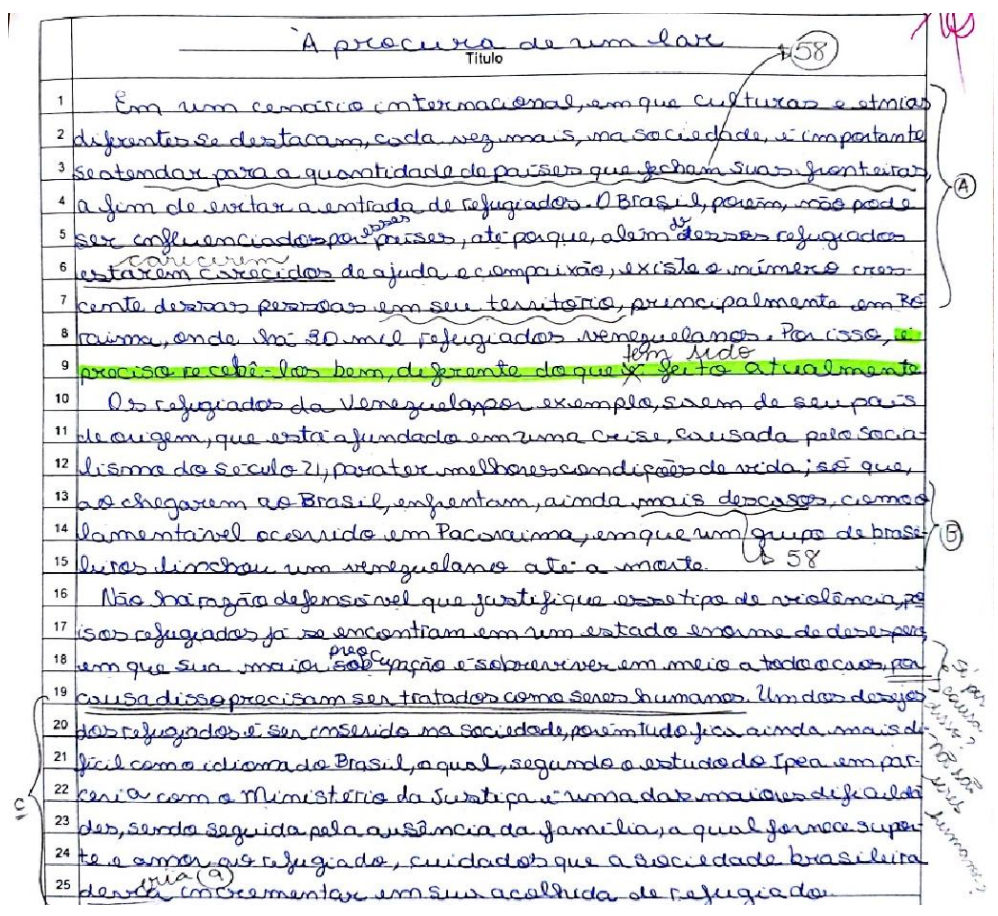

Interfaces da Educ., Paranaíba, v.10, n.28, p. 117 à 143, 2019 


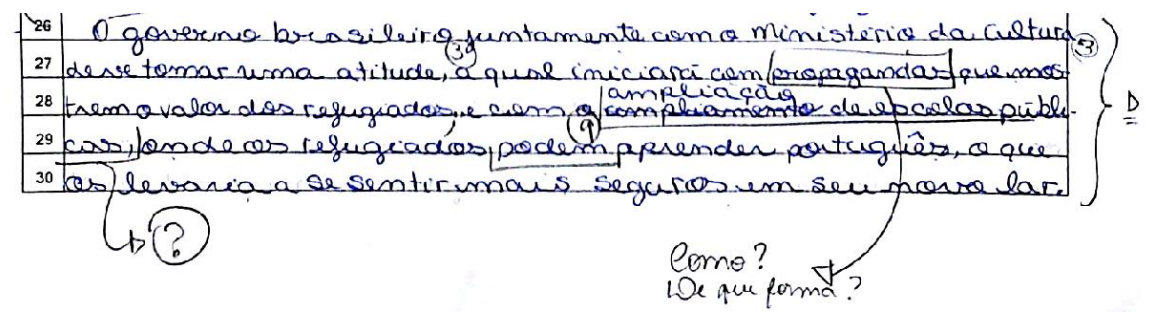

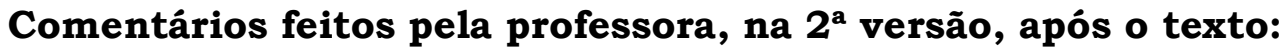

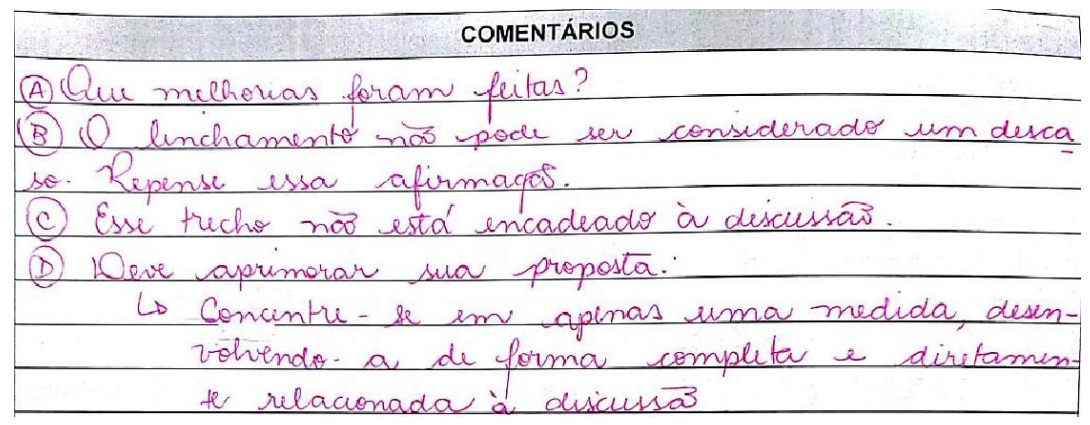

Comparando a $2^{\mathrm{a}}$ versão do texto à $1^{\mathrm{a}}$, nota-se que diversos aspectos pontuados não foram aprimorados na reescrita, como é o caso do trecho presente nas linhas 4 e 5 da primeira versão, "O Brasil, porém, não pode ser influenciado por esses paises (...)", em que a professora, por meio da correção textual-interativa solicitou que a aluna justificasse essa afirmação.

Entretanto, ao se analisar sua $2^{a}$ versão, o problema permanece, como pode ser visto também nas linhas 4 e 5 ; diferente daqueles que foram pontuados por meio da correção resolutiva, que foram corrigidos.

Já nas correções indicativas, nota-se que a aluna substituiu as expressões sublinhadas por outras semelhantes, como pode ser visto por meio da comparação dos trechos presentes na $1^{\text {a }}$ e $2^{\text {a }}$ versão, ambos ocupando a $27^{\mathrm{a}}$ linha: "a qual pode começar" e "a qual iniciará", respectivamente. Provavelmente, a aluna faz esse tipo de substituição, porque, certamente, não compreendeu o problema pontuado pela professora.

\section{Regressão no conteúdo do texto}

Dos 77 textos analisados, em 32 casos, os textos, em vez de evoluírem, apresentaram certo grau de regressão, omitindo partes, resumindo outras. Também nessas versões observou-se a "higienização" do texto. 
Assim como no item anterior, é possivel averiguar que as intervenções feitas pela professora ocorrem de diversas maneiras, havendo o predomínio da resolutiva, da classificatória e da textual-interativa.

\section{Exemplificação de reescrita em que houve regressão no conteúdo quando comparado à primeira versão}

\section{$1^{\text {a }}$ Versão}

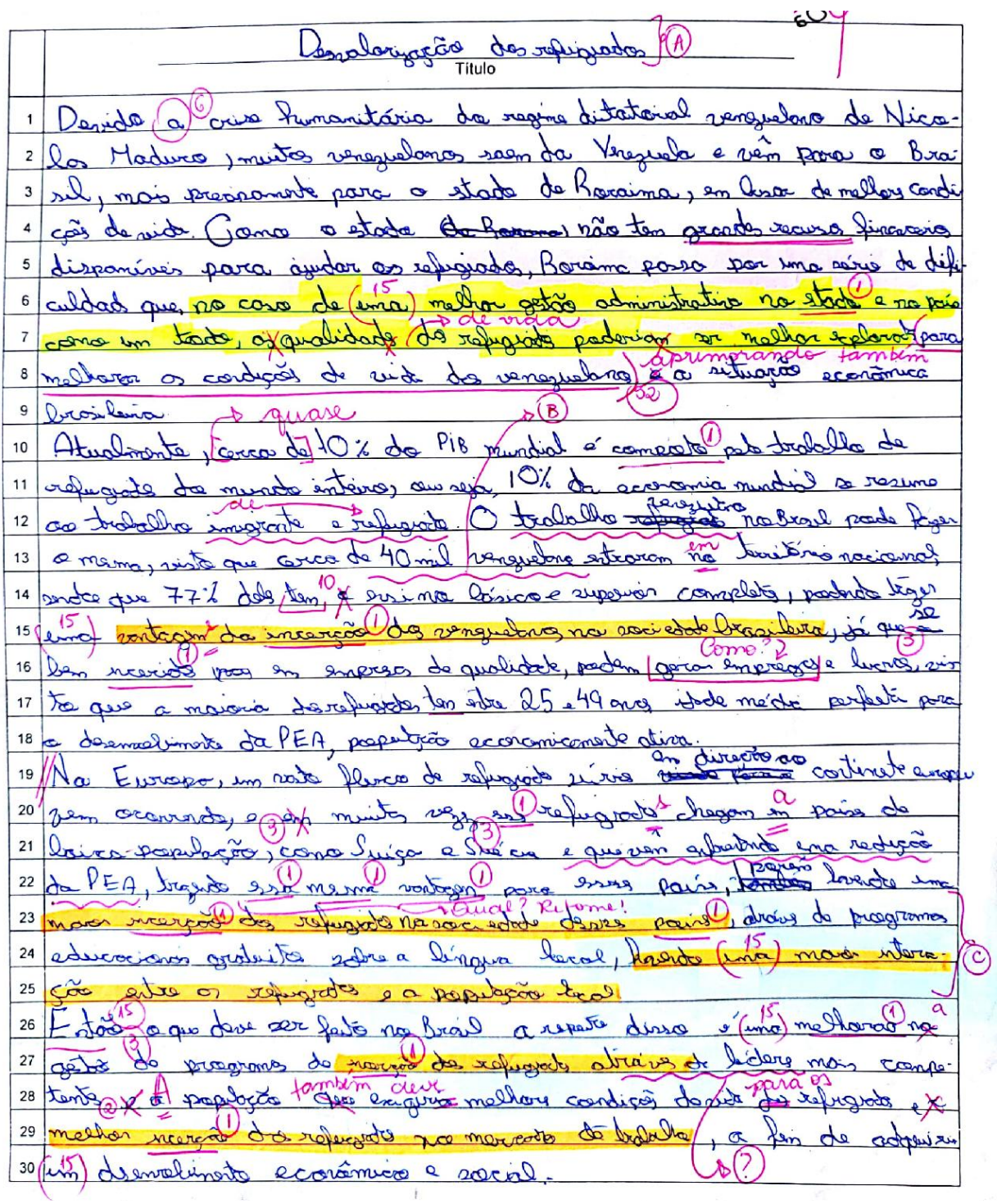




\section{Comentários feitos pela professora após o texto:}

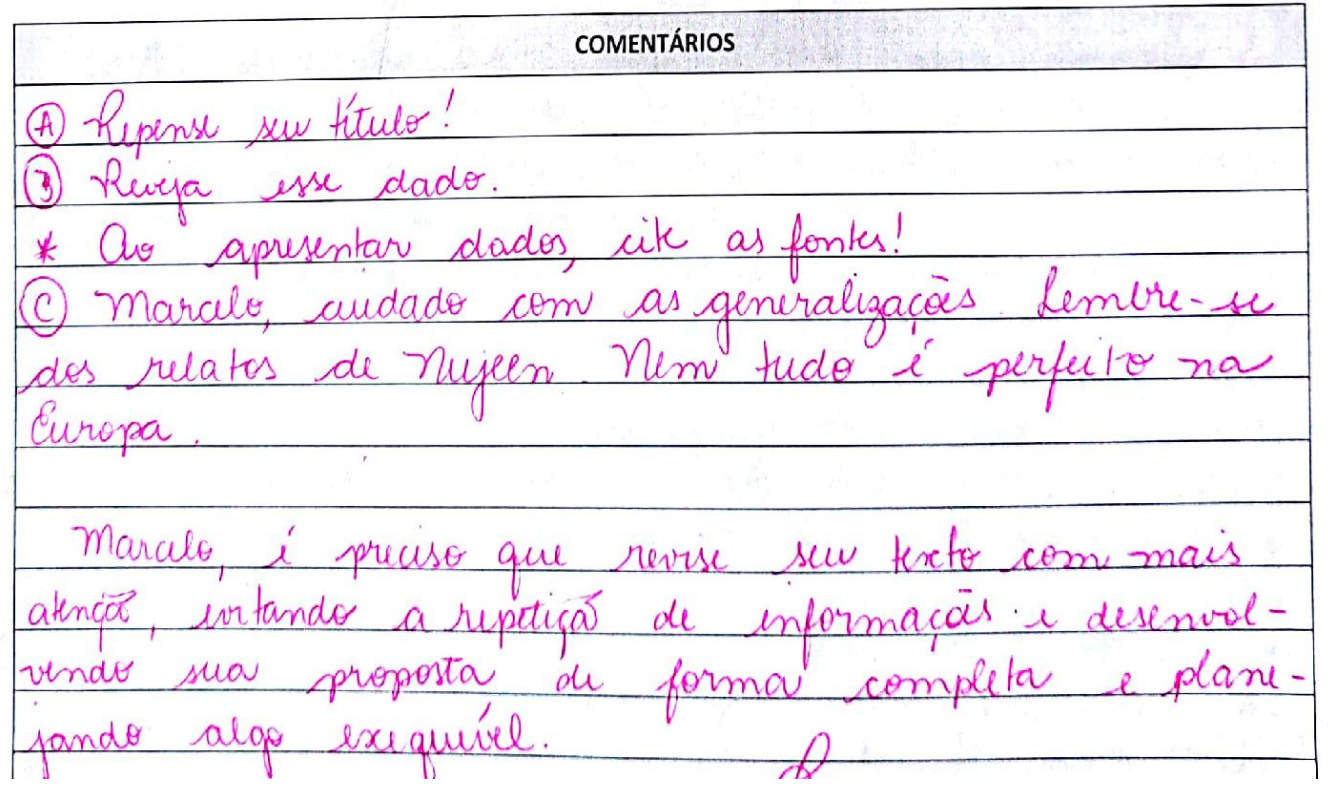

Assim como na redação observada no primeiro caso, percebe-se, nesse texto, a presença também de diferentes formas de correção, predominando a classificatória, seguida pela resolutiva. Embora em menor quantidade, a indicativa também se faz presente, assim como a textual-interativa, empregada em menor quantidade, aparecendo apenas 5 vezes no decorrer do texto.

Nota-se, também, nesse texto, a presença de algumas frases grifadas pela professora de amarelo (diferente da marcação dos alunos para identificar sua tese na introdução), para indicar algo que lhe chamou a atenção, entretanto o aluno não recebeu nenhuma pista de que se tratava.

\section{$2^{\text {a }}$ Versão}




\begin{tabular}{|c|c|}
\hline & Do de \\
\hline & \\
\hline & egime ditatorial na Valez \\
\hline & sainde de seu pais's de oric \\
\hline & goti3 pais Porem, siss 120 \\
\hline & wos rus $2 \mathrm{~m}$ \\
\hline & 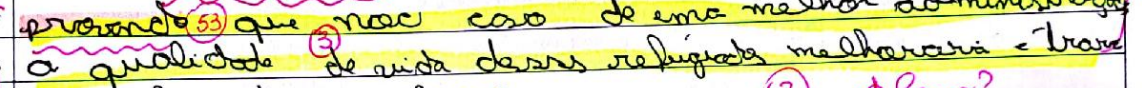 \\
\hline & desamabuimate os Brasil ? plome? \\
\hline 10 & de PiB mundiof é grodo dewète ea \\
\hline & $\begin{array}{l}\text { em um norospais. O } \\
\text { nil Tuisto que } 1120\end{array}$ \\
\hline & ma, padende geror Rmere \\
\hline 14 & paí como enm todo, in \\
\hline 15 & ovas partiem uneriog lá \\
\hline 16 & parumere \\
\hline 18 & 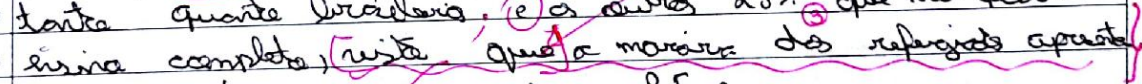 \\
\hline & 19 ono, compontes a P.E.A \\
\hline 20 & wopa, nuits refugiads sta odent \\
\hline & C \\
\hline & Wo \\
\hline & en [para] a i \\
\hline & is de. aprendiforte da lingia \\
\hline & (43) (1) que visam preg \\
\hline & $\begin{array}{l}\text { Para p } \\
\text { raseres, }\end{array}$ \\
\hline & aph \\
\hline & $d$ \\
\hline
\end{tabular}

\section{Comentários feitos pela professora, na $2^{\mathrm{a}}$ versão, após o texto:}

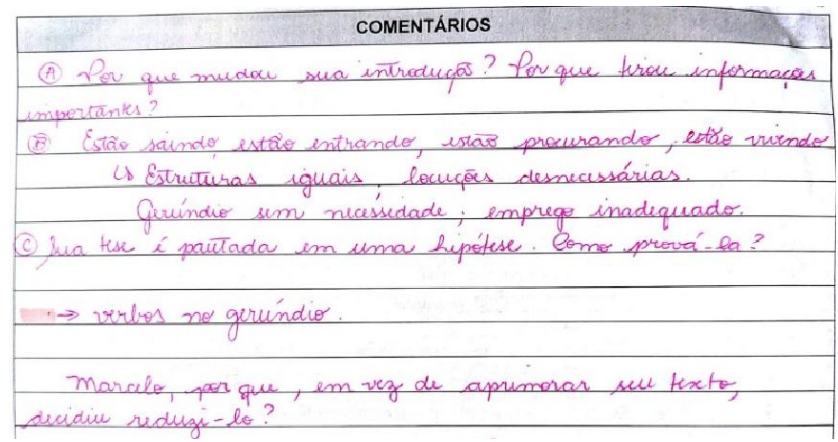

Interfaces da Educ., Paranaíba, v.10, n.28, p. 117 à 143, 2019 
Ao se analisar sua segunda versão, percebe-se a falta de envolvimento do aluno já pela reelaboração de seu título, solicitado pela professora na $1^{\mathrm{a}}$ correção. $\mathrm{Na} 1^{\text {a }}$ versão, o título era “Desvalorização dos refugiados", já na $2^{\mathrm{a}}$ versão, foi reelaborado para “Refugiados desvalorizados". O aluno simplesmente inverteu a ordem das palavras, transformando o substantivo desvalorização em verbo no particípio, desvalorizados, permanecendo o sentido.

Observando a introdução da $1^{\mathrm{a}}$ e da $2^{\mathrm{a}}$ versão, nota-se que a ideia permanece, entretanto a da reescrita está resumida, diversas informações relevantes foram omitidas, nem sequer a correção resolutiva apresentada na última linha da $1^{\mathrm{a}}$ versão foi empregada.

$\mathrm{Na} 1^{\mathrm{a}}$ versão, a professora, por meio da correção textual-interativa, solicitou que o aluno apresentasse a fonte dos dados presentes no $2^{\circ}$ parágrafo, aspecto esse ignorado pelo aluno, uma vez que os números permaneceram na $2^{\mathrm{a}}$ versão sem sua fonte.

Outro fato relevante está centrado na proposta de intervenção presente na $1^{\mathrm{a}}$ versão, a qual se encontra incompleta, conforme observação feita pela professora no "bilhete" após o texto. Porém, ao se analisar a proposta da $2^{\mathrm{a}}$ versão, percebe-se que, além de resumir a ideia da $1^{\mathrm{a}}$, permanece incompleta, novamente ignorando os apontamentos feitos.

\subsubsection{Evolução no conteúdo do texto}

Em 29 reescritas, percebeu-se a evolução nos textos dos alunos. Notou-se, por meio da análise de seus textos, que esse grupo analisou de forma efetiva as intervenções feitas pela professora, bem como realizou sua análise crítica com afinco. Sua reelaboração não ficou presa às intervenções explícitas, mas, sim, a cada detalhe questionado, principalmente por meio da correção textual-interativa.

Observando esse grupo, nota-se que é formado por alunos de alto desempenho, alunos mais dedicados a seus afazeres. Pode ser apenas uma coincidência, entretanto é um aspecto que não pode ser ignorado. 


\section{Exemplificação de reescrita em que houve evolução no conteúdo quando comparado à primeira versão}

\section{$1^{\text {a }}$ Versão}

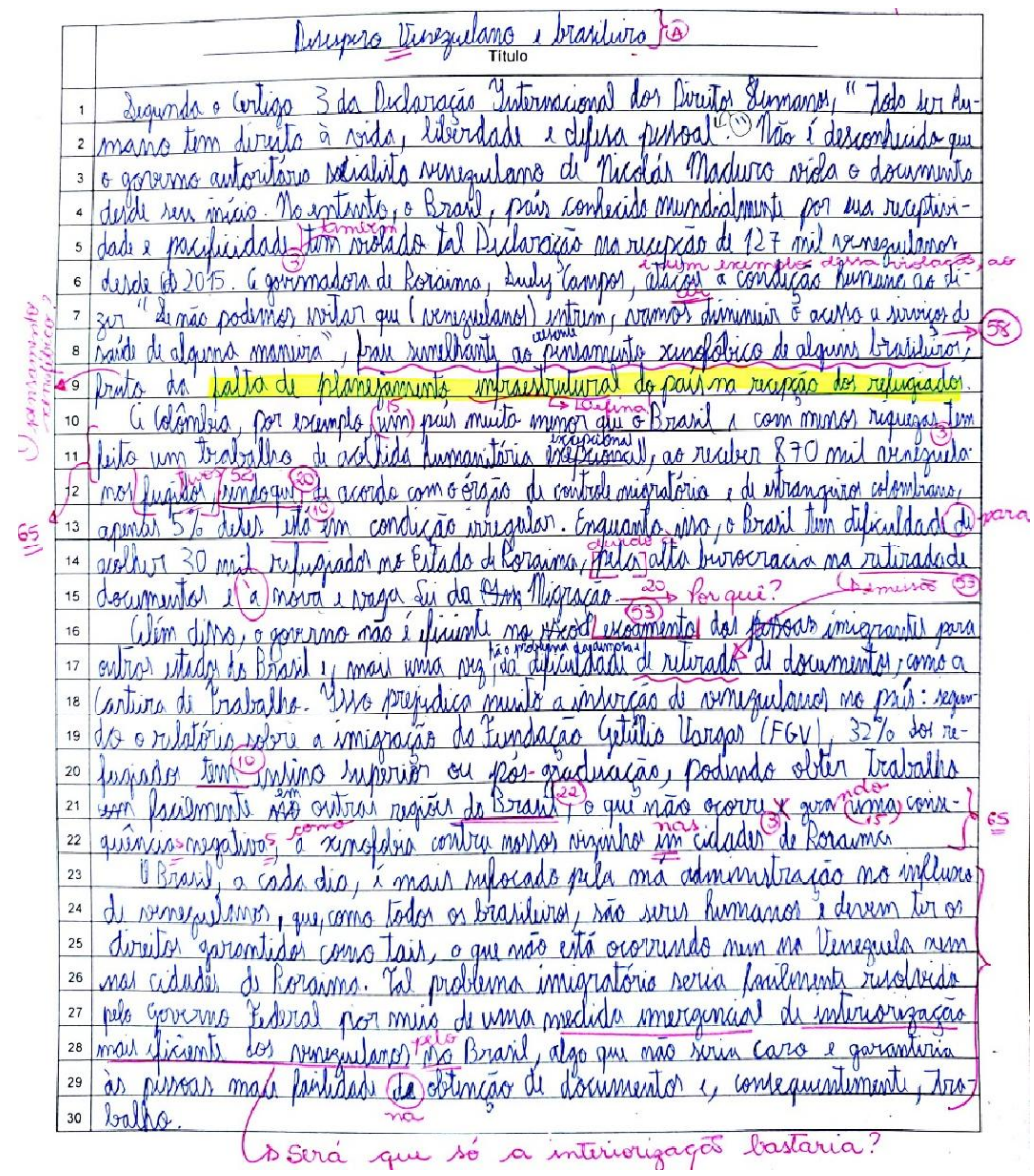

\section{Comentários feitos pela professora após o texto:}

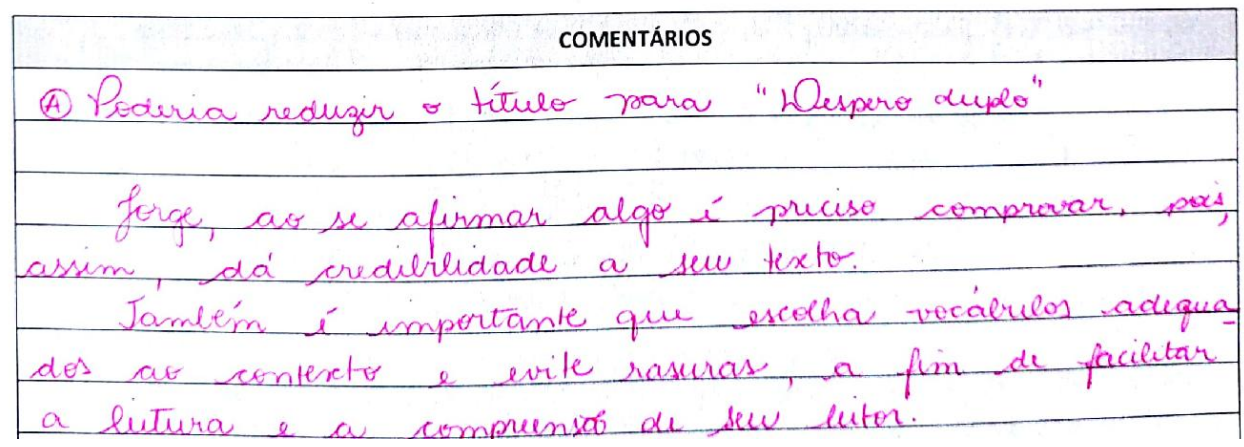

Interfaces da Educ., Paranaíba, v.10, n.28, p. 117 à 143, 2019 
Assim como os demais textos, a professora utilizou-se das diferentes estratégias de correção, prevalecendo nesse texto o emprego das correções resolutiva e classificatória, embora também tenham aparecido, em menor número de ocorrências, a indicativa e a textual-interativa.

\section{$2^{a}$ Versão}

\begin{tabular}{|c|c|}
\hline & Desacolhida fumanitária \\
\hline & 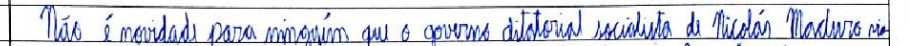 \\
\hline & 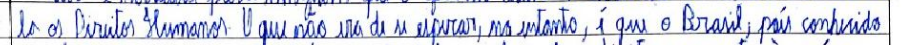 \\
\hline & 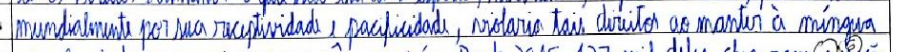 \\
\hline & 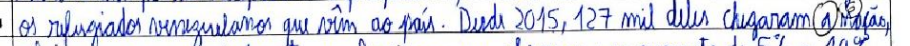 \\
\hline & 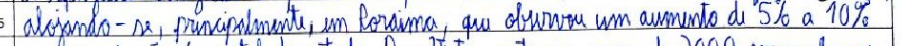 \\
\hline & 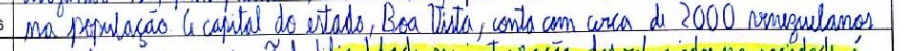 \\
\hline & 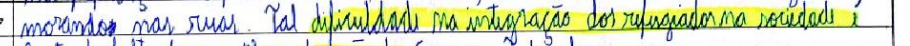 \\
\hline & 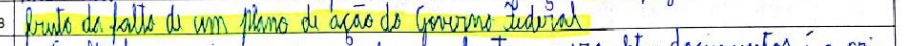 \\
\hline & 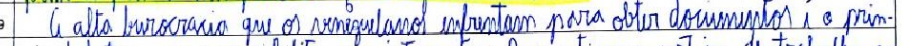 \\
\hline & 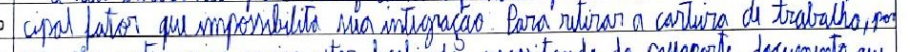 \\
\hline & star ligalizads mecensitands do parlapoote, documento que \\
\hline & 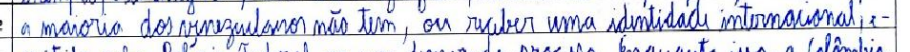 \\
\hline & mitida pela Polvia tederal um un demortado proceriso. Enquasunto isso, a Cómbira. \\
\hline 14 & 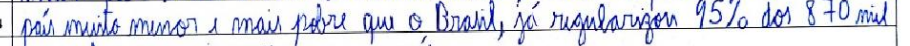 \\
\hline & 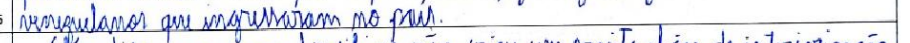 \\
\hline & 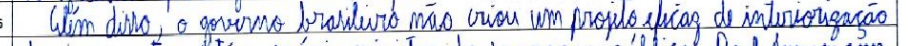 \\
\hline 17 & 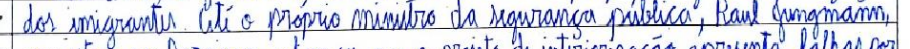 \\
\hline 18 & ami steve un foranma, afunmoen que \\
\hline 19 & questers l woouraticas. Grimde partl dos \\
\hline & 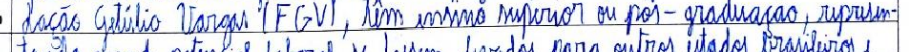 \\
\hline & 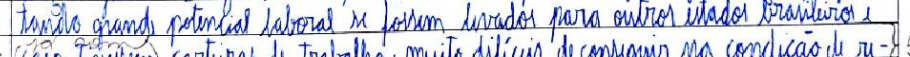 \\
\hline 23 & 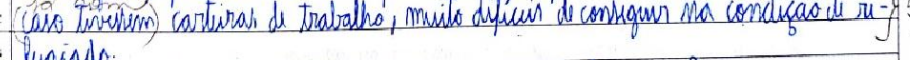 \\
\hline & de nenequelavos que adentraram Rorainice, a prope- \\
\hline 25 & 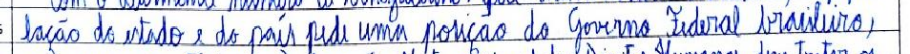 \\
\hline & 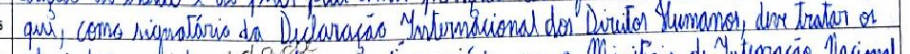 \\
\hline & 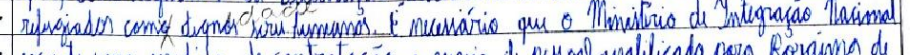 \\
\hline 28 & 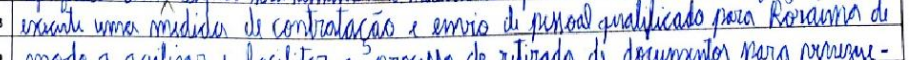 \\
\hline & 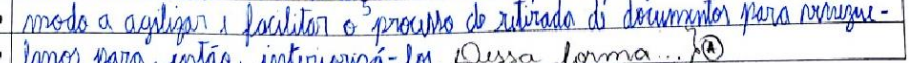 \\
\hline & \\
\hline
\end{tabular}

\section{Comentários feitos pela professora, na $2^{\mathrm{a}}$ versão, após o texto:}




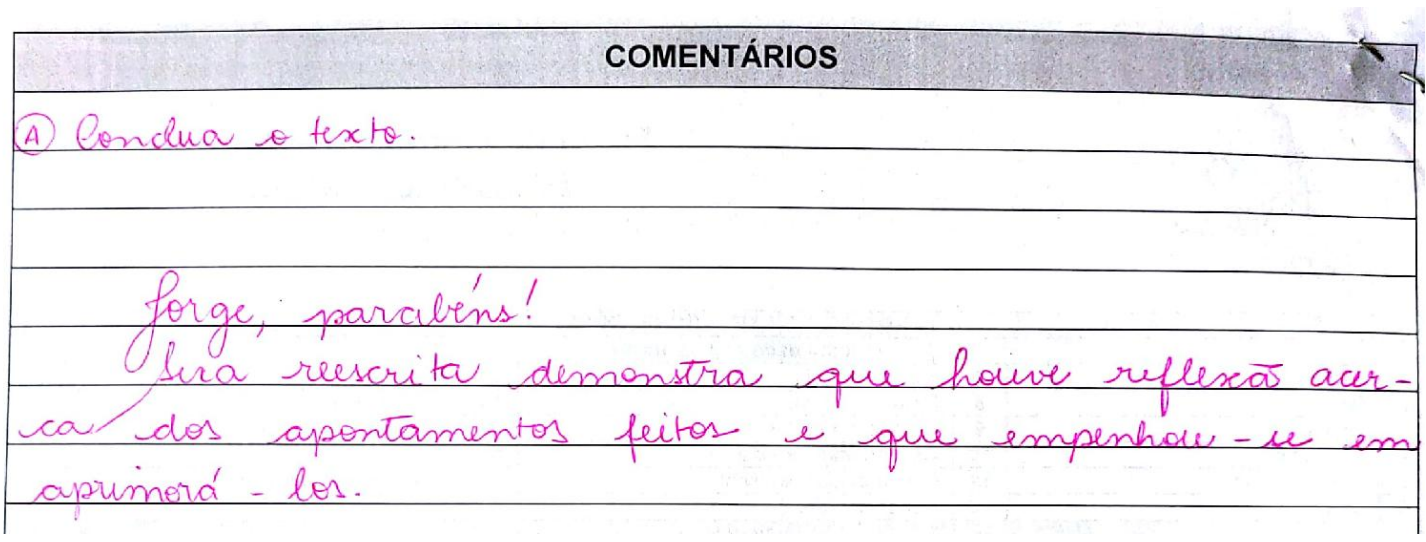

Analisando e comparando as duas versões do texto, é possível observar que o aluno considera as observações feitas pela professora, mas busca, por esforço próprio, a melhor solução para os problemas pontuados, como pode ser visto na reelaboração de seu título. A professora, embora faça uso da correção textual-interativa, sugestiona um título que ela julga ser adequado, porém o aluno o reelabora de forma diferente, de acordo com aquilo que ele acredita ser o ideal para sua nova versão.

É possivel perceber o empenho e a preocupação do aluno com a reelaboração efetiva de seu texto ao se comparar a introdução das duas versões. Embora a ideia permaneça, é notável que a $2^{\mathrm{a}}$ versão apresenta informações mais claras e melhor encadeadas.

Em seu desenvolvimento, na $1^{\text {a }}$ versão, a professora pontuou, por meio do código 65, a ausência de recursos argumentativos, ou seja, a falta de comprovação para a afirmação feita, fato corrigido em sua segunda versão, como pode ser averiguado nos paragrafos 2 e 3 .

Em sua primeira conclusão, a professora questiona se a proposta sugerida pelo aluno, de agilizar a interiorização dos venezuelanos, resolveria o problema; logo, em sua $2^{a}$ versão, ele reflete e propõe algo a ser feito antes da interiorização, que seria a agilização e organização da emissão dos documentos dessas pessoas, para que, com isso em mãos, possam ser interiorizadas.

\section{Considerações Finais}


Ao analisar as reescritas dos alunos, levou-se em consideração o fato de essa prática não ser realizada com frequência no ambiente da escola em que o estudo foi realizado, logo, sabe-se que os alunos não estão habituados a reescrever seus textos, atribuindo, de forma geral, pouco ou nenhum valor ao exercício, pois, para realiza-lo, faz-se necessário dispender tempo e trabalho a fim de que se possa, de fato, atingir o objetivo proposto: o aperfeiçoamento do texto.

Entretanto, com base nos estudos de Ruiz (2015), a reescrita não é um trabalho único e exclusivo do aluno, pois se trata de um diálogo entre o aluno e o professor - por meio da primeira versão de um texto; e entre o professor e o aluno - por meio da correção devolvida ao aluno. Por isso, a forma como esse texto é corrigido e devolvido ao aluno tem grande influência em seu processo de reelaboração.

Se o aluno se vê diante de um texto em que há predomínio da correção resolutiva, acomoda-se, pois os problemas encontrados pelo professor já foram solucionados por ele próprio, tornando a tarefa da reescrita bastante tranquila, já que o estudante preocupar-se-á apenas com a cópia daquilo que está exposto sobre sua escrita, sem que precise analisar seu texto, nem ir em busca de novas alternativas que visem melhorá-lo.

Esse tipo de correção pode ser bastante danoso para o aluno, pois não promove nem incentiva sua reflexão acerca daquilo que escreveu, pois, após copiar o texto, dá sua tarefa como encerrada, repetindo, provavelmente, os mesmos equívocos em produções futuras.

De acordo com a análise das 77 reescritas, percebeu-se que a correção resolutiva predominava em todos os textos observados; seguida pela correção classificatória, que, embora requeira esforço do aluno, no sentido de consultar a tabela de transgressões, apresenta o problema presente no trecho de forma mais acessivel; diferente da correção textual-interativa, que demanda do aluno um esforço além, que consiste em analisar a escrita do professor, refletir sobre o apontamento feito em seu texto, e, por fim, buscar a solução para essa intervenção. 
Observou-se nos textos que apresentaram evoluções quanto aos problemas pontuados que a correção textual-interativa promove maior protagonismo do aluno no processo de reescrita, dessa forma, nota-se o quão importante é o uso dessa estratégia para que o autor do texto aprimore-o.

Diante desse levantamento, é importante refletir sobre alguns aspectos da prática, principalmente, a do professor. Sabe-se que o trabalho de correção de redação não é uma tarefa fácil, pois implica em uma leitura bastante minuciosa do texto do aluno, que demanda tempo e esforço. Logo, diante de inúmeras redações e de prazos pré-determinados, o professor se vê obrigado, muitas vezes, a adotar estratégias que agilizem seu processo de correção. As quais, infelizmente, como visto, podem atrapalhar esse processo de aprimoramento da escrita.

Portanto, para que o diálogo pretendido entre os agentes envolvidos nessa dinâmica - aluno e professor - seja, de fato, efetivo, faz-se necessário que a prática da reescrita seja uma constante em sala de aula, que o aluno seja instrumentalizado para essa tarefa, a fim de que o objetivo de aprimoramento seja realmente alcançado.

Também se faz necessário repensar as formas de intervenção do professor no texto do aluno, pois é a partir da correção feita e devolvida ao aluno que seu processo de reescrita se inicia.

\section{Referências bibliográficas}

BENVENISTE, Émile. Da subjetividade na linguagem. In: Problemas de linguística geral I. 5. ed. Campinas: Pontes Editores, 2005, p. 284- 293.

BRASIL. Ministério da Educação. Base Nacional Comum Curricular (BNCC). Educação é a Base. Brasília, MEC/CONSED/UNDIME, 2017. Disponível em: http: / / basenacionalcomum.mec.gov.br/wpcontent/uploads/2018/02/bncc-20dez-site.pdf. Acesso em 05 nov. 2018.

CAVALCANTI, Jauranice Rodrigues. Professor, leitura e escrita. São Paulo: Contexto, 2015.

CAYSER, Elisane Regina; CRESTANI, Luciana Maria; DIEDRICH, Marlete Sandra. As formas de intervenção do professor no texto do aluno e a 
construção da intersubjetividade. Fórum linguistic., Florianópolis, v.13, n.3, p.1415 - 1429 , jul./ set.2016.Disponível em: https:// periodicos.ufsc.br/index.php/forum/article/viewFile/19848412.201 6v13n3p1415/32722. Acesso em 01 nov. 2018.

FERREIRA, Elisa Cristina Amorim; ARAUJO, Denise Lino de. $O$ (não) funcionamento da reescrita em textos produzidos por licenciandos em letras. Trab. linguist. apl. [online]. 2014, vol.53, n.1, pp.201-224. ISSN 2175764X. Disponivel em: http://www.scielo.br/scielo.php?pid=S010318132014000100011\&script=sci _abstract\&tlng=pt. Acesso em 04 nov. 2018.

RUIZ, Eliana Donaio. Como corrigir redações na escola: uma proposta textualinterativa. São Paulo: Contexto, 2015. 